\title{
アンモニアおよび苛性ソーダ水溶液による硫化水来の吸収*
}

\author{
疋田晴 夫**.浅井语** \\ 日. 昔 吉 紀**. 石 原 立 害** \\ 大阪府立大学工学部 化学工学科
}

\section{腥 䡒}

各種のアルカリ水寉による $\mathrm{H}_{2} \mathrm{~S}$ の吸収操作は湿式 脱硫法として工莱的に重要であるにすかかわらず，その 反応吸収機橉に阅する定量的な研究はきわめて少なく， 濡れ壁塔での灾騟結果に基ついて $\mathrm{NaOH}$ 水溶液、 $\mathrm{Na}$ $\mathrm{CO}_{3}-\mathrm{NaHCO}_{3}$ 便溶液, モノェタノールフミン水溶夜 による $\mathrm{H}_{2} \mathrm{~S}$ の反応吸收機粠を考察した Astarita ら の研究があるにすきない。

著者らは $\mathrm{H}_{2} \mathrm{~S}-\mathrm{NH}_{3}$ 水溶液系括よび $\mathrm{H}_{2} \mathrm{~S}-\mathrm{NaOH}$ 水溶 夜系の反応吸収機棬を解明する目的で，液柱塔を用いて これら両系の反级吸収実嗆を行ない，吸収速度の実測值 を曼透説に基つく理論吸収速度と比较検討した。以下そ の結果の概要を報告する。

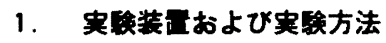

本研究で用いた夜柱茖および実呀装置の主要部は前 報》の $\mathrm{CO}_{2}-\mathrm{NaOH}$ 水溶夜系の反応吸収実馀で用いたす のとは䚾同棫である。 $\mathrm{H}_{2} \mathrm{~S}$ ガスとしてはボンべからの純 ガスを水蒸気で飽和させたすのを使用し，その吸収速度 は前報”の場合と同しく石けん膜流量計によって測定し た。曼収液としては純水 $\left(25^{\circ} \mathrm{C}, 30^{\circ} \mathrm{C}\right), 0.125 \sim 1.0$ $\mathrm{g} \cdot \mathrm{mol} / \mathrm{l}$ の $\mathrm{NH}_{3}$ 水溶液 $\left(30^{\circ} \mathrm{C}\right), 0.125 \sim 2.0 \mathrm{~g} \cdot \mathrm{mol} / \mathrm{l}$ の $\mathrm{NaOH}$ 水溶液 $\left(25^{\circ} \mathrm{C}\right)$ を使用し，これらの吸収液に微 目の界面活性郕（花王石けん株式会社製、スコフロール 100）を添加した场合と添加しない㘯合について実唭を

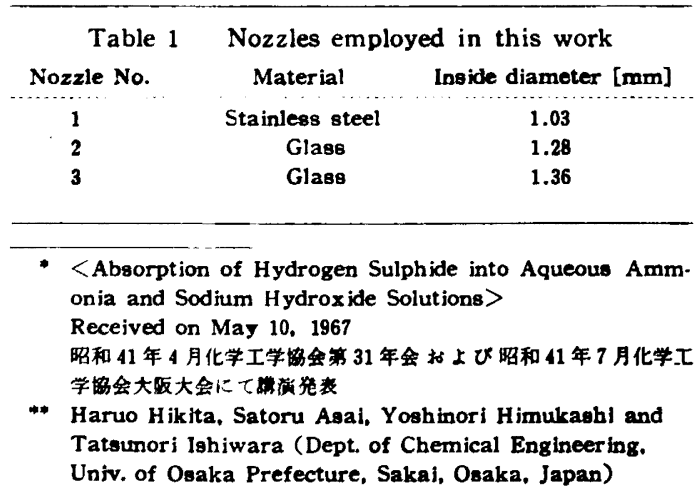

行なった。また全瀑度 $0.123 \sim 0.963 \mathrm{~g} \cdot \mathrm{mol} / \mathrm{l}$, 自由 $\mathrm{NH}_{3}$ 港度 $0.060 \sim 0.465 \mathrm{~g} \cdot \mathrm{mol} / \mathrm{l}$ の $\mathrm{NH}_{3}-\mathrm{NH}_{4} \mathrm{HS}$ 混合水溶液 （界面活性剤添加、30 $\mathrm{C}$ ）による $\mathrm{H}_{2} \mathrm{~S}$ の吸収実験もあわ せ行なった。

本研究で用いた液柱塔の液ノズルは Table 1 に示した 3 種で，その形状はScriven ら8が用いたすのとはば同 一である。なおこれらの液ノルズから生成される液柱の 内部への吸収速度が漫透説に基つく理論値ときわめて良 好な一致を示し，端効果が無視できることは，本研究に 先立ち純 $\mathrm{CO}_{2}$ の水による物理吸収実験を行なって確認 した。

\section{2. $\mathrm{H}_{2} \mathrm{~S}$ の水による吸収}

Fig. 1 は $25^{\circ} \mathrm{C}$ おび $30^{\circ} \mathrm{C}$ における $\mathrm{H}_{2} \mathrm{~S}$ 一水系の物 理吸収実葐の結果を平均吸収速度 $N_{\mathrm{A}}^{*}$ 対気液接触時間 $t$ の対数点㥪として示したもので，図中の実線は漫透説 に基つく理論吸収速度

$$
N_{A}^{*}=2 \sqrt{D_{A} / \pi t} A_{i}
$$

を表わす。 $N_{A}$ *の理論値を計算するさいに必要な $\mathrm{H}_{2} \mathrm{~S}$ の水に対する物理溶解度 $A_{i}$ としては Winkler ${ }^{13)}$ の実 測値 $3.37 \times 10^{-3} \mathrm{~g} / \mathrm{cm}^{3}\left(25^{\circ} \mathrm{C}\right), 2.97 \times 10^{-3} \mathrm{~g} / \mathrm{cm}^{3}\left(30^{\circ}\right.$ C）使用し，また $\mathrm{H}_{2} \mathrm{~S}$ の水中抬散係数 $D_{1}$ としては Hagenbach ${ }^{6)}$ の $15.5^{\circ} \mathrm{C}$ に括ける実測值 $1.44 \times 10^{-5} \mathrm{~cm}^{2}$ /secに Stokes-Einsteinの式による温度補正を行なっ た値 $1.87 \times 10^{-5} \mathrm{~cm}^{2} / \mathrm{sec}\left(25^{\circ} \mathrm{C}\right), 2.12 \times 10^{-5} \mathrm{~cm}^{2} / \mathrm{sec}$

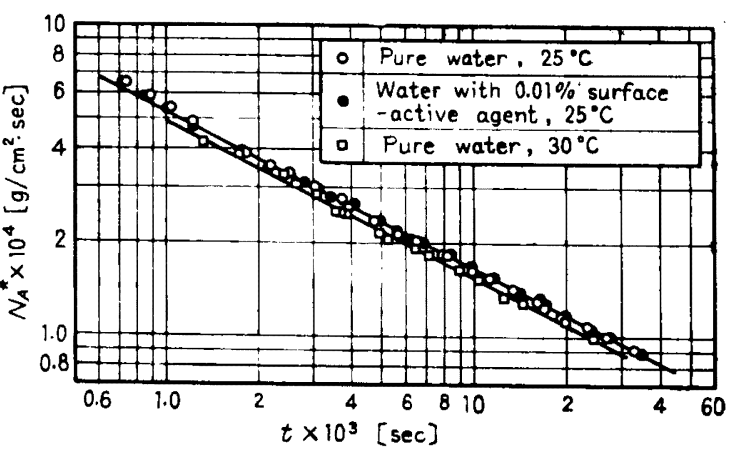

Fig. 1 Absorption of $\mathrm{H}_{2} \mathrm{~S}$ into water with and without surface-active agent (No.1 nozsle) 


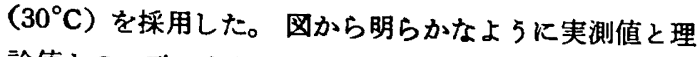
論値との一致はきわめて良好であり，また界面活性刜を 添加した場合と添加しない場合とで吸収速度には何らの 差す認められない。

\section{$3 \cdot 1$ 反応吸収機䉼}

水溶夜中での $\mathrm{H}_{2} \mathrm{~S}$ と $\mathrm{NH}_{3}$ との反応はつきの 2 段逐次 反応にしたがって進行するるのと考えられる。

$$
\begin{aligned}
& \mathrm{H}_{2} \mathrm{~S}+\mathrm{NH}_{3}=\mathrm{NH}_{4}{ }^{+}+\mathrm{HS}^{-} \\
& \mathrm{HS}^{-}+\mathrm{NH}_{3}=\mathrm{NH}_{4}{ }^{+}+\mathrm{S}^{--}
\end{aligned}
$$

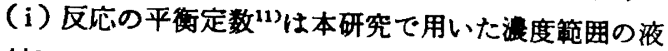
に対しては 350 程度の值であってかなり大きいか，（ii） 反応の平简定数は無限希杓水容液に対して $10^{-6}$ ぐらい の值であってきわめて小さいから、工学的な取り报いで は（ii）の反応を無視し（i）の可逆反応だけがおこる としても差支えないであろう。また(i)の反応はプロト ン交換のイオン反応で，その反底速度はきわめて迅速で

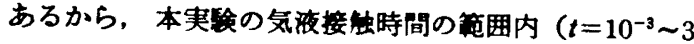
$\left.\times 10^{-2} \mathrm{sec}\right)$ ではこの反応を瞬間反㢈とみなしても差支 えなかろ5。以上の考察により， $\mathrm{H}_{2} \mathrm{~S}$ の $\mathrm{NH}_{3}$ 水溶液に よる吸取仕（i）の可逆间反底学伴了吸取として取り 扱いらることが予想される。

浸透説に基つく場合には， $\mathrm{A}+\mathrm{B} \rightleftharpoons \mathrm{E}+\mathrm{F}$ なる可逆瞬 間反応を伴亏吸収に対する基睖分分程式は一般的には 解けないが，各成分の液相扩散保数がすへて等しいとき には解析的に解くことができ，理詥吸収速度として次式 が得られる。（付䥄 1 参照）

$$
\begin{aligned}
& N_{\mathbf{A}}=\beta\left(2 \sqrt{D_{A} / \pi t}\right)\left(A_{t}-A_{0}\right) \\
& \sqrt{\left(\frac{E_{0}}{A_{\mathfrak{t}}}+\frac{F_{0}}{A_{\mathfrak{t}}}+K\right)^{2}+4 K\left(\frac{B_{0}}{A_{\mathfrak{t}}}\right)\left(1-\frac{A_{0}}{A_{\mathfrak{l}}}\right)} \\
& -\left(\frac{E_{0}}{A_{i}}+\frac{F_{0}}{A_{i}}+K\right) \\
& \beta=1+ \\
& 2\left(1-\frac{A_{0}}{A_{\imath}}\right)
\end{aligned}
$$

$$
E_{0} F_{0} / A_{0} B_{0}=K
$$

（i）の反応に対しては，各成分の液相払散俰数がすへ て等しいとい5条件は满足されないが，それそれの抾散 係数の値にはそれ活ど大きな差はない゙から，Eq. (2 b)を (i) の可逆瞬間反応を伴 5 吸収に対する反応㐿数 $\beta$ の理 論式として用いても大した誤りはないるのと思われる。 Fig. 2 は Eqs. (2b)，(2c)による $\beta$ 対 $B_{0} / A_{t}$ の成㐿を 図示したるので，実線は $K=350 ， E_{0}=F_{0}$ の場合の $\beta$

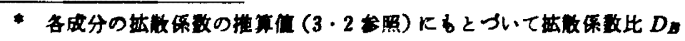
$/ D_{A}, D_{E} / D_{A}, D_{F} / D_{A}$ t林货してろると. $D_{B} / D_{A}=1.27 \sim 1.28$, $D_{E} / D_{A}=D_{F} / D_{A}\left(=D_{P} / D_{A}\right)=0.958 \sim 0.966$ となる。

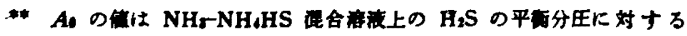
van Krevelen ら"1)の实刑式を用いて推策した。

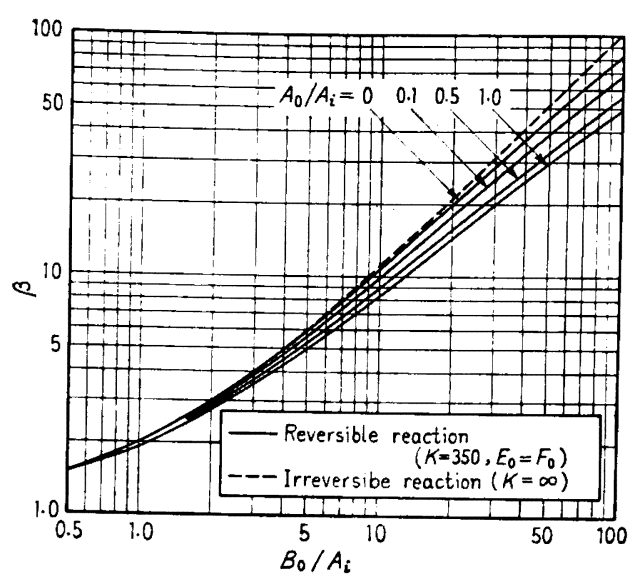

Fig. 2 Reaction factor for absorption with reversible reaction $A+B \rightarrow E+F\left(D_{A}=D_{B}=D_{E}=D_{F}\right)$

Table 2 Physical properties for $\mathrm{H}_{2} \mathrm{~S}-\mathrm{NH}_{3}$ solution system at $30^{\circ} \mathrm{C}$ $\begin{array}{cccccc}B_{0} & P_{\mathrm{c}} & A_{i} \times 10^{3} & D_{A} \times 10^{5} & D_{B} \times 10^{5} & D_{B} / D_{A} \\ {[\mathrm{~g} \cdot \mathrm{mol} / l]} & {[\mathrm{g} \cdot \mathrm{mol} / l]} & {\left[\mathrm{g} / \mathrm{cm}^{3}\right]} & {\left[\mathrm{cm}^{2} / \mathrm{sec}\right]} & {\left[\mathrm{cm}^{2} / \mathrm{sec}\right]} & {[-]}\end{array}$

\begin{tabular}{llllll}
0.125 & 0.144 & 3.03 & 2.11 & 2.68 & 1.27 \\
0.250 & 0.288 & 3.10 & 2.09 & 2.66 & 1.28 \\
0.340 & 0.391 & 3.14 & 2.08 & 2.66 & 1.28 \\
0.345 & 0.397 & 3.15 & 2.08 & 2.66 & 1.28 \\
0.350 & 0.403 & 3.15 & 2.08 & 2.66 & 1.28 \\
0.50 & 0.576 & 3.23 & 2.06 & 2.64 & 1.28 \\
1.00 & 1.15 & 3.51 & 2.01 & 2.59 & 1.29 \\
\hline
\end{tabular}

を, 点線は $K=\infty$, すなわち不可逆瞬間反応吸収の場合 の $\beta$ を表わす。本研究の実䜽条件下では $B_{0} / A_{i}$ の値は 0.7 10，の範囲附にあり，また $A_{0} / A_{i}$ の值**は $\mathrm{NH}_{3}$ $\mathrm{NH}_{4} \mathrm{HS}$ 混合溶液に対しても0.04 以下であって近似的に は0とみなすことができるが Fig. 2によればこのよう な条件下での $\beta$ は不可逆瞬間反応吸収に対する $\beta$ とほと んどー致する。そこで著者らは（i）の反応が本研究の 実検条件下で恃不可逆瞬間反応とみなせるものとして, 実験結果を浸透説に基つく不可逆瞬間反応吸収 $(\mathrm{A}+\mathrm{B} \rightarrow$ P) の理論式"

$$
\begin{aligned}
& N_{A}=\beta\left(2 \sqrt{D_{A} / \pi t}\right) A_{i} \\
& \beta=1 / \operatorname{erf}(\sigma) \\
& \sqrt{\frac{D_{B}}{D_{A}}}\left(\frac{B_{0}}{A_{i}}\right) \exp \left\{\sigma^{2}\left(1-\frac{D_{A}}{D_{B}}\right)\right\} \operatorname{erf}(r) \\
& +\operatorname{erf}\left(\sqrt{D_{A} \sigma}\right)=1
\end{aligned}
$$

と比校検討した。

\section{$3 \cdot 2$ 各程物性值の推基}

浸透説に基つく不可逆間反応吸収の理論によれは。 気液界面と反応面との間には反応生成物 $P$ が近似的に次 式（付野 2 参照）

$$
P_{c}=P_{0}+\sqrt{D_{B} / D_{P}} B_{0}
$$

で与えられる一定㳻度 $P_{\mathrm{c}}$ を保持して存在しており，溶 
Table 3 Physical properties for $\mathrm{H}_{2} \mathrm{~S}-\mathrm{NH}_{3}-\mathrm{NH}_{4} \mathrm{HS}$ solution system at $30^{\circ} \mathrm{C}$

\begin{tabular}{|c|c|c|c|c|c|c|c|c|}
\hline $\begin{array}{c}B_{0} \\
{[\mathrm{~g}-\mathrm{mol} / \mathrm{l}]}\end{array}$ & $\begin{array}{c}P_{0} \\
{[\mathrm{~g} \cdot \mathrm{mol} / l]}\end{array}$ & $\underset{[\mathrm{g} \cdot \mathrm{mol} / l]}{T}$ & $\begin{array}{c}\boldsymbol{P}_{c} \\
{[\mathrm{~g}-\mathrm{mol} / l]}\end{array}$ & $\begin{array}{l}A_{0} \times 10^{6} \\
{\left[\mathrm{~g} / \mathrm{cm}^{3}\right]}\end{array}$ & $\begin{array}{r}A_{i} \times 10^{3} \\
{\left[\mathrm{~g} / \mathrm{cm}^{3}\right]}\end{array}$ & $\begin{array}{r}D_{A} \times 10^{5} \\
{\left[\mathrm{~cm}^{2} / \mathrm{sec}\right]}\end{array}$ & $\begin{array}{c}D_{B} \times 10^{5} \\
{\left[\mathrm{~cm}^{2} / \mathrm{sec}\right]}\end{array}$ & $\begin{array}{c}D_{B} / D_{A} \\
{[-]}\end{array}$ \\
\hline 0.060 & 0.063 & 0.123 & 0.132 & 6.73 & 3.03 & 2.11 & 2.68 & 1.27 \\
\hline 0.106 & 0.377 & 0.483 & 0.499 & 13.5 & 3.19 & 2.07 & 2.63 & 1.27 \\
\hline 0.128 & 0.125 & 0.253 & 0.272 & 12.9 & 3.09 & 2.09 & 2.66 & 1.27 \\
\hline 0.253 & 0.240 & 0.493 & 0.531 & 23.5 & 3.21 & 2.07 & 2.64 & 1.28 \\
\hline 0.372 & 0.123 & 0.495 & 0.551 & 4.31 & 3.22 & 2.07 & 2.64 & 1.28 \\
\hline 0.465 & 0.498 & 0.963 & 1.033 & 52.3 & 3.45 & 2.02 & 2.58 & 1.28 \\
\hline
\end{tabular}

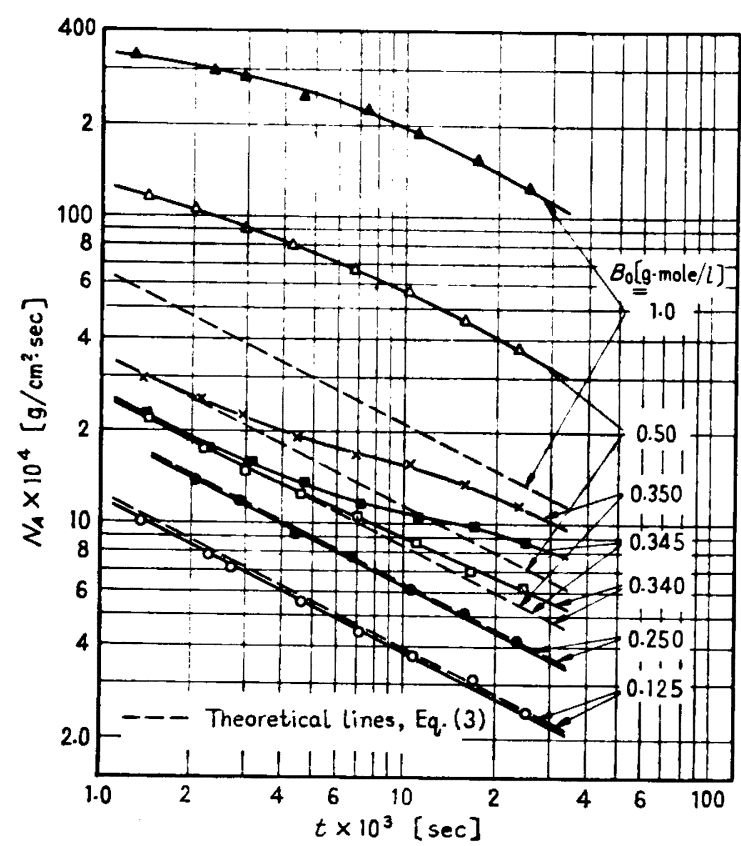

Fig. 3 Absorption of $\mathrm{H}_{2} \mathrm{~S}$ into aqueous $\mathrm{NH}_{3}$ solutions without surface-active agent at $30^{\circ} \mathrm{C}$ (No.2 nozzie)

筫ガス $A$ はこの液に溶解し，引き繶きこの液中を反応

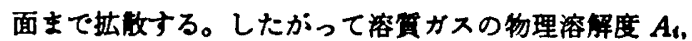

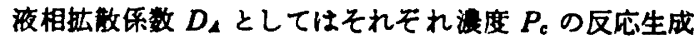
物客液飞対する值を使用すべきである。そこで著者らは $A_{1} ， D_{4}$ の推算に先立ち，ます Eq.(4)を用いて $\mathrm{H}_{2} \mathrm{~S}$ と $\mathrm{NH}_{3}$ との反底生成物 $\mathrm{NH}_{4} \mathrm{HS}$ の界面近傍での一定浱 $P_{c}$ を算出した。この計算に必要な $D_{B} / D_{P}$ の值，すなわ ち $\mathrm{NH}_{3}$ と $\mathrm{NH}_{4} \mathrm{HS}\left(\mathrm{NH}_{4}{ }^{+}+\mathrm{HS}^{-}\right)$の液相桩散㐿数の比と しては，Arrhenius ${ }^{1)}$ による $\mathrm{NH}_{3}$ の水中払散係数の実 测値 $1.64 \times 10^{-5} \mathrm{~cm}^{2} / \mathrm{sec}\left(12^{\circ} \mathrm{C}\right)$ に温度補正を行なった 值 $2.69 \times 10^{-5} \mathrm{~cm}^{2} / \mathrm{sec}\left(30^{\circ} \mathrm{C}\right)$ と Nernst の推算式を用 いて算出した無限希积水溶液中での $\mathrm{NH}_{4} \mathrm{HS}$ の抾散係数 $2.03 \times 10^{-5} \mathrm{~cm}^{2} / \mathrm{sec}\left(30^{\circ} \mathrm{C}\right)$ との比 1.325 を採用し，こ の值が $\mathrm{NH}_{3}$ 渡度 $B_{0}$ には無関保に一定であると仮定し た。

$\mathrm{NH}_{4} \mathrm{HS}$ 水溶液に対する $\mathrm{H}_{2} \mathrm{~S}$ の物理溶解度 $A_{6}$ は次式

$$
\log \left(A_{i} / A_{i w}\right)=-k_{t} I
$$

によって推算した。ただ 塩類奻果保数 $k$ ，の值として
は，実測値が見当らないので, $\mathrm{H}_{2} \mathrm{~S}-\mathrm{NaHS}$ 水溶液系に

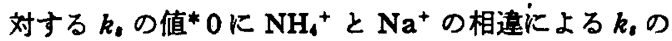
差(10)を補正した值一0.063 を使用した。

$\mathrm{H}_{2} \mathrm{~S}$ の $\mathrm{NH}_{4} \mathrm{HS}$ 水溶液中での拡散係数 $D_{4}$ としては 水中拡散俰数 $2.12 \times 10^{-5} \mathrm{~cm}^{2} / \mathrm{sec} K$ ，著者らが実測 した NH.HS 水溶液の粘度の補正を行なった值を用い た。また $\mathrm{NH}_{3}$ の夜相払散俰数 $D_{B}$ の值は水中払散俰 数 $2.69 \times 10^{-5} \mathrm{~cm}^{2} / \mathrm{sec}$ に水溶液の粘度補正を行なっ て算出した。ただしこの場合の水溶液粘度としては， 液相本体の $\mathrm{NH}_{3}$ 水容液または $\mathrm{NH}_{3}-\mathrm{NH}_{4} \mathrm{HS}$ 混合溶夜 の粘度と文液界面近策の $\mathrm{NH}_{4} \mathrm{HS}$ 水溶液の粘度との算 術平均値を使用した。

Table 2 および 3 はそれそれれ上述の推算法によって 求めた $\mathrm{NH}_{3}$ 水溶液拉よび $\mathrm{NH}_{3}-\mathrm{NH}_{4} \mathrm{HS}$ 混合溶液に対 する各種物性値を表示したるのである。

\section{3 实臨桔果人教事}

Fig. 3 は吸収液に界面活性郕を添加せずに行なった $\mathrm{H}_{2} \mathrm{~S}-\mathrm{NH}_{8}$ 本溶液系の反应吸収実験の結果を平均吸収 速度 $N_{4}$ 対気液接蛙時間 $t$ の関保として対数点緅した のので，四中の破線は Table 2 の各物性値を用いて Eq.（3）から算出した $N_{\Lambda}$ の理論線である。 $N_{\Lambda}$ の実測 值は $\mathrm{NH}_{3}$ 水溶液の度 $B_{0}$ が低い堨合には理論線と きわめてよく一致するか， $B_{0}$ の值が增すにつれてした いに理論吸収速度よりす高い值をとるよ5になり， $B_{0}=$ $0.50 \mathrm{~g} \cdot \mathrm{mol} / \mathrm{l}$ の场合には理諭值の約 5 倍, $B_{0}=1.0 \mathrm{~g} \cdot \mathrm{mol}$ $1 /$ の埸合には理論値の約 10 倍の異常に高い吸収速度を 示す。著者らは $N$ のの実測値と理論値との差異を界面摚 乱現象によるすのであろらと推論した。このような界面 摚乱現象については主に液液抽出の分野で研究が行なわ

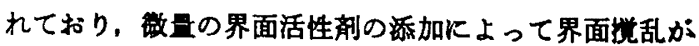
阻止できることが明らかにされている。そこて著者らは 上述の推論を確かめる目的で，吸収液に界面活性都を 0.05 0.2 vol\%添加してふたたび吸収実験を行なっ た。Fig. 4 はその結果を示したすので， $\mathrm{NH}_{3}$ 瀑度 $B_{0}$ が $0.125 \sim 1.0 \mathrm{~g}-\mathrm{mol} / \mathrm{l}$ の 4 種の吸収液に対する $N_{4}$ の実測 値はいずれす理論式 Eq.(3)を表わす破線と良好な一致

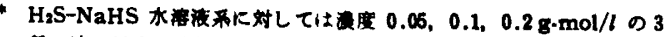

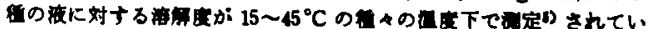

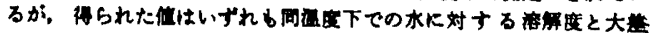
なく, $k_{0}=0$ とみななことがてをる。
} 


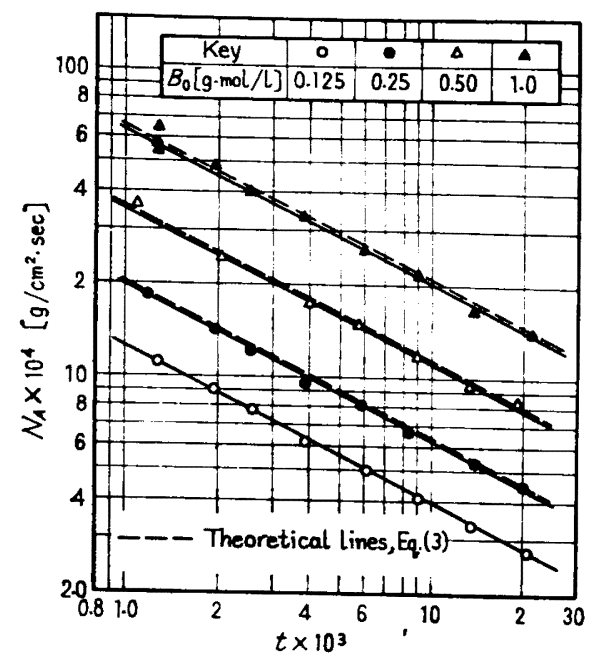

Fig. 4 Abeorption of $\mathrm{H}_{2} \mathrm{~S}$ thto aqueous $\mathrm{NH}_{3}$ solutions with aurface-active agent at $30^{\circ} \mathrm{C}$ (No. 2 nozzle)

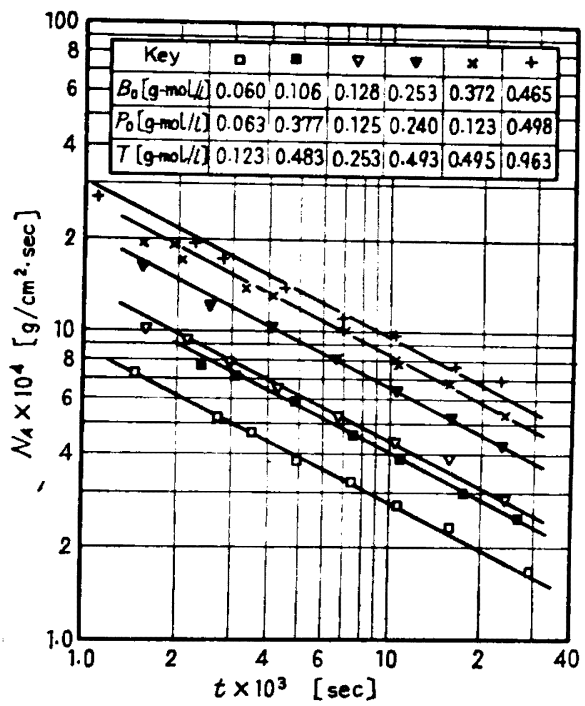

Fig. 5 Absorption of $\mathrm{H}_{2} \mathrm{~S}$ into aqueous $\mathrm{NH}_{5}-\mathrm{NH}, \mathrm{HS}$ solutions with surface-active agent at $30^{\circ} \mathrm{C}$ (No. 3 nozzle)

を示している。この結果から Fig. 3 における $N_{4}$ の実 測値と理論値との不一致は著者らが推諭したよ5 界面 港乱に基因するすのであると考えてよかろら。

Fig. 5 は $\mathrm{NH}_{3}-\mathrm{NH}_{4} \mathrm{HS}$ 混合溶液（界面活性郕 $0.2 \mathrm{vol}$ \%添加）による $\mathrm{H}_{2} \mathrm{~S}$ の吸収実稀の結果を示したすので， 各夢収液に対する吸収速度 $N_{4}$ はいずれる気液接触時間 $t$ の $-1 / 2$ 乗に比例して変化しており，また $t$ の同一值 のもとでは自由 $\mathrm{NH}_{3}$ 瀑度 $B_{0}$ の值の大きい吸収夜活ど 高い吸収速度を示している。

Fig. 6 は Fig. 4 および Fig. 5 と示した $N_{A}$ の実測値 の代表線に基ついて算出した反応俰数 $\beta\left(=N_{A} / N_{A}^{*}\right)$

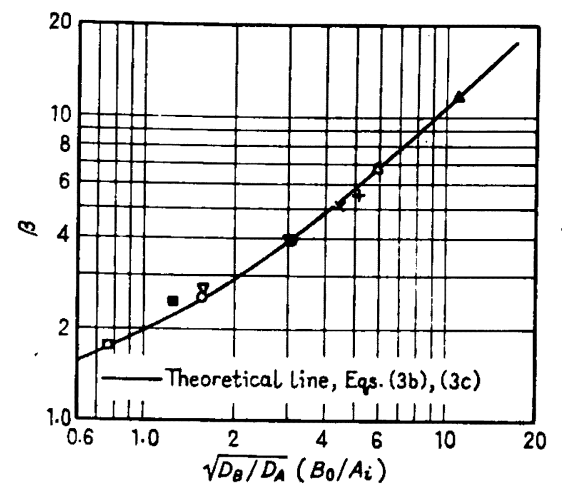

Fig. 6 Reaction factor for absorption of $\mathrm{H}_{2} \mathrm{~S}$ into a queous $\mathrm{NH}_{3}$ and $\mathrm{NH}_{3}-\mathrm{NH}_{4} \mathrm{HS}$ solutions with surface-active agent

Table 4 Physical properties for $\mathrm{H}_{2} \mathrm{~S}-\mathrm{NaOH}$ solution system at $30^{\circ} \mathrm{C}$

\begin{tabular}{cccccc}
$\begin{array}{c}B_{0} \\
{[\mathrm{~g}-\mathrm{mol} / l]}\end{array}$ & $\begin{array}{c}P_{0} \\
{[\mathrm{~g}-\mathrm{mol} / l]}\end{array}$ & $\begin{array}{c}A_{i} \times 10^{3} \\
{\left[\mathrm{~g} / \mathrm{cm}^{3}\right]}\end{array}$ & $\begin{array}{c}D_{A} \times 10^{3} \\
{\left[\mathrm{~cm}^{2} / \mathrm{sec}\right]}\end{array}$ & $\begin{array}{c}D_{B} \times 10^{5} \\
{\left[\mathrm{~cm}^{2} / \mathrm{sec}\right]}\end{array}$ & $\begin{array}{c}D_{B} / D_{A} \\
{[-]}\end{array}$ \\
\hdashline 0.125 & 0.165 & 3.37 & 1.85 & 3.77 & 2.04 \\
0.25 & 0.330 & 3.37 & 1.82 & 3.70 & 2.03 \\
0.50 & 0.661 & 3.37 & 1.76 & 3.54 & 2.01 \\
1.00 & 1.32 & 3.37 & 1.63 & 3.23 & 1.98 \\
2.00 & 2.64 & 3.37 & 1.34 & 2.61 & 1.95 \\
\hline
\end{tabular}

の値を $\sqrt{D_{B} / D_{A}}\left(B_{0} / A_{i}\right)$ に対して点緅し，これらを $\beta$ の理論式 Eq. (3 b) そ比校したものであるか， $\beta$ の実測 値と理論値との一致はかなり良好である。この結果から 界面擋乱が起こらない場合の $\mathrm{H}_{2} \mathrm{~S}-\mathrm{NH}_{3}$ 水液系および $\mathrm{H}_{2} \mathrm{~S}-\mathrm{NH}_{3}-\mathrm{NH}_{4} \mathrm{HS}$ 混合溶夜系の反応吸収がともに $\mathrm{H}_{2} \mathrm{~S}$ $+\mathrm{NH}_{3} \rightarrow \mathrm{NH}_{4}{ }^{+}+\mathrm{HS}^{-}$の反応を不可逆瞬間反応とみなし た反応吸収理論によって定量的に取り报えることがわか ろ。ただし $B_{0} / A_{1}$ の值が本研究の実検範囲での值より すかなり大きい场合，すなわち比较的湌度の高い $\mathrm{NH}_{3}$ 水溶液で気相中の微量の $\mathrm{H}_{2} \mathrm{~S}$ を吸収する垛合，および $A_{0} / A_{t}$ の值が大きい场合，すなわち $\mathrm{NH}_{4} \mathrm{HS}$ を多量化含 む $\mathrm{NH}_{3}-\mathrm{NH}_{4} \mathrm{HS}$ 混合溶液を吸収液とする場合には,

Fig. 2 からす明らかなよらに不可逆舞反应吸収として の解析はかなりの諢差を生じるすのと思われる。

\section{4. $\mathrm{H}_{2} \mathrm{~S} の \mathrm{NaOH}$ 水溶液による吸収}

\section{1 反応吸収機灌}

$\mathrm{H}_{2} \mathrm{~S}$ と $\mathrm{NaOH}$ とは水溶液中でつぎの上5に反応する あのと考えられる。

$$
\begin{aligned}
& \mathrm{H}_{2} \mathrm{~S}+\mathrm{OH}^{-}=\mathrm{HS}^{-}+\mathrm{H}_{2} \mathrm{O} \\
& \mathrm{HS}^{-}+\mathrm{OH}^{-}=\mathrm{S}^{--}+\mathrm{H}_{2} \mathrm{O}
\end{aligned}
$$

ただし（iii）反応の平符定数は約 $10^{7}$ できわめて大き く，また（iv）反応の平衡定数は 0.1 程度の值で十分小 さいから, 工学的には（iv）反応を無視し（iii）反応を 不可逆反応とみなして取り扱いらるすのと思われる。ま 


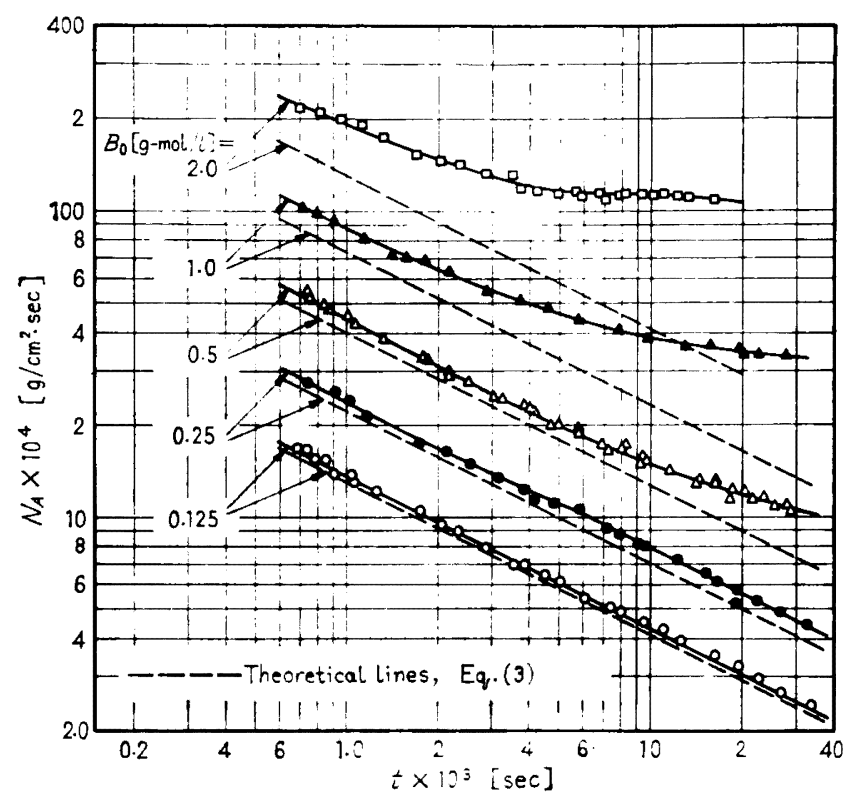

Fig. 7 Absorption of $\mathrm{H}_{2} \mathrm{~S}$ into aqueous $\mathrm{NaOH}$ solutions without surface-active agent at $25 \mathrm{C}$ (No.1 nozzle)

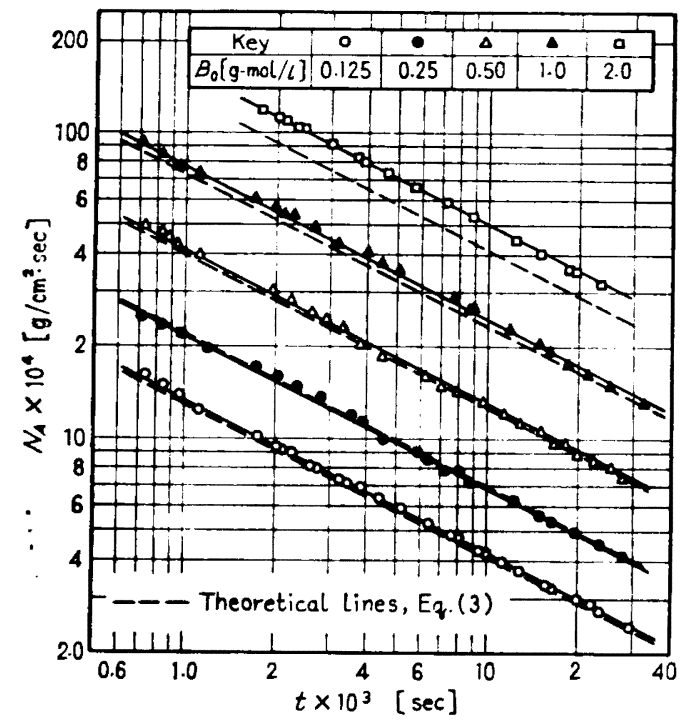

Fig. 8 Abeorption of $\mathrm{H}_{2} \mathrm{~S}$ into aqueous $\mathrm{NaOH}$ solutions with surface-active agent at $25 \mathrm{C}$ (No.l nozzle)

た（iii）反応はフワトン交換反応であるからその反応速 度はきわめて迅速で，本研究の実鈋条件下では瞬間反应 とみなしても差支えないであろ5。以上の考察により著 者らは $\mathrm{H}_{2} \mathrm{~S}-\mathrm{NaOH}$ 水溶没采の反应吸収実験の結果を侵 透説に基つく不可逆瞬間反庆吸収の理論式 Eq.(3)と比 校検討した。

\section{2 各程物性值の推基}

各種物性値の推算は $\mathrm{H}_{2} \mathrm{~S}-\mathrm{NH}_{3}$ 水溶液系の场合と
同粎な方法で行なった。

まず Eq.(4)を用いて $\mathrm{H}_{2} \mathrm{~S}$ と $\mathrm{NaOH} と の$ 反応生成物 NaHS の界面灌度 $P_{\mathrm{c}}$ を算出し たが、このさい $D_{B} / D_{P}$ の值としてはVino$\operatorname{grad} 5^{12)}$ の推算法によって求めた $\mathrm{OH}^{-}$と HS-のそれそれれ無限希积水溶液中での液相 払散係数の值 $3.84 \times 10^{-5} \mathrm{~cm}^{2} / \mathrm{sec}$ と $2.20 \times$ $10^{-5} \mathrm{~cm}^{2} / \mathrm{sec}$ との比 1.745 を採用した。

$\mathrm{H}_{2} \mathrm{~S}$ の NaHS 木溶液に対する物理溶解度 $A_{\mathrm{i}}$ としては水に対する值 $3.37 \times 10^{-3} \mathrm{~g} / \mathrm{cm}^{3}$ $\left(25^{\circ} \mathrm{C}\right)$ をそのまま用いた（3－2 脚注参照）。 また $\mathrm{H}_{2} \mathrm{~S}$ の NaHS 水溶液中の扗散保数 $D_{A}$ としては水中払散俰数 $1.87 \times 10^{-5} \mathrm{~cm}^{2} / \mathrm{sec}$ に，著者らが実測した NaHS 水溶液の粘度 の補正を行なった値を使用した。 $\mathrm{OH}^{-}$の执 散俰数 $D_{B}$ の值も上述の無限希积水溶液に対 する值に， $\mathrm{H}_{2} \mathrm{~S}-\mathrm{NH}_{3}$ 水溶液系の場合と同様 な水溶液の粘度補正を行なって算出した。以 上のよ5な方法で推算した各種物性值を Table 4 に表示する。

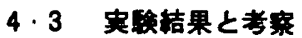

Fig. 7 および 8 はそれそれ吸收液に界面活性郕を添 加しなかった場合および $0.01 \mathrm{vol} \%$ 添加した場合の実 験結果を理論式 Eq. (3) と比校したるのである。Fig. 7 から明らかなよ5に, 界面活性剤を添加しなかった場合 には， $\mathrm{NaOH}$ 灣 $B_{0}$ か $0.25 \mathrm{~g} \cdot \mathrm{mol} / l$ 以上の 4 種の吸 収液に対する吸収速度 $N_{1}$ はすへて理諭吸収速度よりる 高い值を示したが，界面活性倣を添加した場合の $N_{\mathbf{A}}$ の 实測值は、Fig. 8 に示したよ 5 に, $B_{0}=2.0 \mathrm{~g} \cdot \mathrm{mol} / \mathrm{l}$ の 吸収液に対する結果をのぞけば，理論線とかなりよく一 致した。以上の結果から $\mathrm{H}_{2} \mathrm{~S}-\mathrm{NaOH}$ 水溶液系の反応吸 収においても， $\mathrm{H}_{2} \mathrm{~S}-\mathrm{NH}_{3}$ 水溶夜系の反応吸収の場合ほ どではないかかかなりはげしい界面拱乱のおこることが推 論され，また界面活性㓣を吸收液に添加して界面擋乱を 阻止した場合の反応吸収速度は（iii）反応すなわち $\mathrm{H}_{2} \mathrm{~S}$ $+\mathrm{OH}^{-} \rightarrow \mathrm{HS}^{-}+\mathrm{H}_{2} \mathrm{O}$ を不可逆瞬間反応とみなした反応吸 収理論の理論値とかなり良好な一致を示すことが明らか となった。

$\mathrm{H}_{2} \mathrm{~S}-\mathrm{NaOH}$ 水溶液系の反応吸収に関しては Astarita

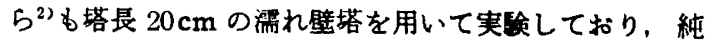
水扰よび $B_{0}=0.105 \sim 0.960 \mathrm{~g}-\mathrm{mol} / l$ の 4 種の瀑度の $\mathrm{Na}$ $\mathrm{OH}$ 水溶液に上る純 $\mathrm{H}_{2} \mathrm{~S}$ の吸収速度を約 $20^{\circ} \mathrm{C}$ の温度の

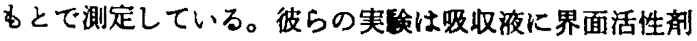
を添加せず，流下液膜の表面に波立らが存在する流動条 件下で行なわれたりので, 各稙湛度の $\mathrm{NaOH}$ 水溶液に 対する反応吸収速度および純水に対する物理吸収速度の 实測值はいずれす浸透跴に基つく理論吸収速度上りすか なり大きかったが，物理吸収速度の実測值を基逴として 
算出した反応俰数の值は理論値と大体一致した。Fig. 9 は Astarita 5の反応保数 $\beta$ の值を理論式 Eqs. (3b), （3c）と比較したるので，同図中には Fig. 8 に示した界 面活性肪を添加した吸収波による $N_{\Delta}$ の実測値から算出 した $\beta$ の值すあわせ点棳してある。．Astarita らの $\beta$ の 値が理論値と一政するといら結果は，反応吸収速度に対 する彼らの実測値と理論値との差翼か弾に液膜表面の波 立ちに基つく乱れによるものであうて，本研究で認めら れたよ5な界面擋乱によるるのではないことを意味して いる。著者らは界面擋乱に上万反店吸収速度の增大効果 は一般に気液接触時間が增すにつれて增大するがやがて 一定となり，その後はかえって娍少するのではないかと 考えており，吸収夜に界面活珄成を添加していないにる かかわらず Astarita らの実呀結果に界面擋乱の影慗か： 認められなかったのは，䌸らの実験が本研究におけるよ

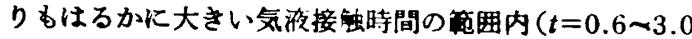
sec）で行なわれたため，界面摚乱効果が無視小であっ たからであろらと想像している。界面摚乱努果が気液接 䖵時間の增大につれて減小するとい5煩向は本研究では 確かめられなかったか， $\mathrm{CO}_{2}$-MEA（モノェタノールフ

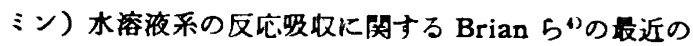
実験結果にはこの碩向が明礁に認められている。Brian らは短い需れ壁塔を用いて各種漫度の MEA 水容液に よる $\mathrm{CO}_{2}$ の吸収実邪を行なった結果， $t=0.15 \sim 0.40$ sec の籍囲内での反店吸收速度が浸透説に基つく理論吸 収速度よりるはるかに大きい值を示すことを見い出し， 実測値と理論値との差巽を著者らと同しく界面谠乱に基 因するるのと結論したが，彼らの测定した界面擋乱奻果 は液流速の減少，すなわち気液接時間の增大とともに 減少している。

\section{結言}

夜柱塔を用いて純 $\mathrm{H}_{2} \mathrm{~S}$ の $\mathrm{NH}_{3}$ 木溶液および $\mathrm{NaOH}$ 水溶液による反统吸取実験を，吸収液に界面活性剂を添 加した場合と添加しない場合とについて行ない，各場合 の吸収速度の実测值を浸透説:基つく理諭吸収速度と比 较検討した。その結果, 界面活性郕の存在下での $\mathrm{H}_{2} \mathrm{~S}-$ $\mathrm{NH}_{3}$ 水溶液系括よび $\mathrm{H}_{2} \mathrm{~S}-\mathrm{NaOH}$ 水溶液系の反応吸収速 度は。それぞれ $\mathrm{H}_{2} \mathrm{~S}+\mathrm{NH}_{3} \rightarrow \mathrm{NH}_{4}{ }^{+}+\mathrm{HS}^{-}$および $\mathrm{H}_{2} \mathrm{~S}+$ $\mathrm{OH}^{-} \rightarrow \mathrm{HS}^{-}+\mathrm{H}_{2} \mathrm{O}$ を不可逆瞬間反応とみなした反応吸収 理論飞基つく理論吸収速度と良好な一致を示すことが確 かめられた。また吸収液に界面活性郕が含まれていない 場合には， $\mathrm{H}_{2} \mathrm{~S}-\mathrm{NH}_{3}$ 水溶液系および $\mathrm{H}_{2} \mathrm{~S}-\mathrm{NaOH}$ 水溶 液系化対する反応吸収速度がすれす理論吸收速度より す著しく大きい値を示すことを認め，これを界面䙺乱現 象に基因するものと推論した。 。

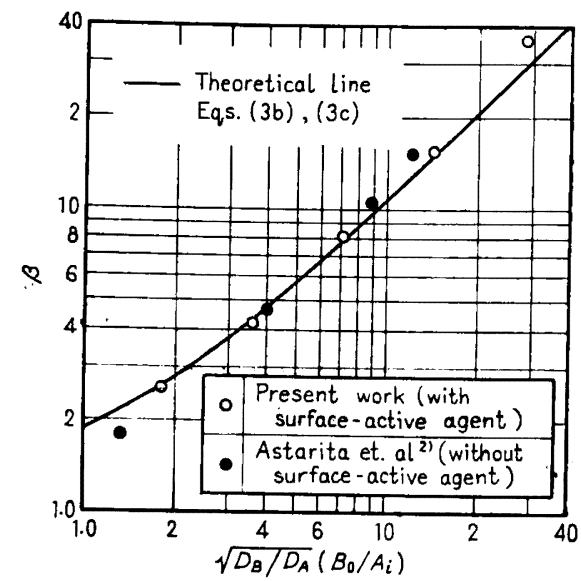

Fig. 9 Reaction factor for absorption of $\mathrm{H}_{2} \mathrm{~S}$ into aqueous $\mathrm{NaOH}$ solutions

[ 付 記 ] 本研究の费用の一部は昭和 38 年度扰上び昭和 41 年度文部省各個研究费によった。ここに厚く腤意を表する。ま た実跧に協力していたたいた高塚富夫; 横谷勇の両君にも深く 感部与る。

付 録

1. 间可道反 $(\mathbf{A}+\mathbf{B} \rightleftharpoons \mathbf{E}+\mathbf{F})$ を伴う吸収の場合の吸収 速度の理諗野

この場合の各成分の液相内払散に対する基礎徽分方程式は， 唚透説にもとつけばつぎの諸式

$$
\begin{aligned}
& \partial A / \partial t=D_{A}\left(\partial^{2} A / \partial x^{2}\right)-r \\
& \partial B / \partial t=D_{B}\left(\partial^{2} B / \partial x^{2}\right)-r \\
& \partial E / \partial t=D_{E}\left(\partial^{2} E / \partial x^{2}\right)+r \\
& \partial F / \partial t=D_{F}\left(\partial^{2} F / \partial x^{2}\right)+r
\end{aligned}
$$

のよ5になり，初期条件，境界条件としてはつぎの各式

$$
\left.\begin{array}{cc}
t=0, \quad x>0 ; & A=A_{0}, B=B_{0}, E=E_{0}, F=F_{0} \\
x=0, t>0 ; & A=A_{i}, D_{B}(\partial B / \partial x)+D_{E}(\partial E / \partial x)=0 \\
& D_{E}(\partial E / \partial x)-D_{F}(\partial F / \partial x)=0 \\
x \rightarrow \infty, t \geq 0 ; & A=A_{0}, B=B_{0}, E=E_{0}, F=F_{0}
\end{array}\right\}
$$

が通用できる。ただし Eq.(A-1) 中の r恪成分の反応による

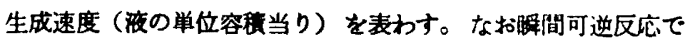
は液相内のいたる処で化学平衡か成立するから，各成分の瀑度 相互間火は $x$ の値のいかんにかかから节次式の関伱か成り立つ。

$$
E F / A B=K
$$

Eqs. (A-1) (A-3) は $D_{A} \neq D_{B} \neq D_{E} \neq D_{F}$ の场合には解析 的に解くことが困数なので，以下では $D_{B}=D_{E}=D_{F} \equiv D_{A}$ とし て理論解を慗出する。

Eq.(A-1)の $A, B, E$ 各成分に対する式をそれぞれ $F$ 成分 に対する式と組み合わせて反応速度項 $r$ を消去すると

$$
\begin{aligned}
& \partial(A+F) / \partial t=D_{\mathbf{A}}\left[\partial^{2}(A+F) / \partial x^{2}\right] \\
& \partial(B+F) / \partial t=D_{\mathbf{A}}\left[\partial^{2}(B+F) / \partial x^{2}\right] \\
& \partial(E-F) / \partial t=D_{\mathbf{A}}\left[\partial^{2}(E-F) / \partial x^{2}\right]
\end{aligned}
$$

となるから，これらの式を Eq. (A-2) の諸条件を用いて解けは兄 つぎの各式が得られる。 


$$
\begin{aligned}
& A+F=A_{0}+F_{0}+\left(A_{i}+F_{i}-A_{0}-F_{0}\right) \operatorname{erfc}\left(x / 2 \sqrt{D_{A} t}\right) \\
& B+F=B_{0}+F_{0} \\
& E-F=E_{0}-F_{0}
\end{aligned}
$$

ただし $F_{i}$ は気液界面での $\mathrm{F}$ 成分の湛度を表わす。

溶貿ガス A の瞬同吸收速度 $N_{A i}$ は，末反応の A 成分と反応 によって生じた $\mathrm{F}$ 成分の気液界面での液相内払散速度の和に等 しいから $D_{F}=D_{A}$ のときには $N_{A i}=-D_{A}[\partial(A+F) / \partial x]_{x=0}$ と なりこの式に Eq. $(\mathrm{A}-5 \mathrm{a})$ を代入すれば㐸式が得られる。

$$
N_{A t}=\left(A_{i}+F_{i}-A_{0}-F_{0}\right) \sqrt{D_{A} / \pi t}
$$

したがって平均吸收速度 $N_{4}$ は $N_{A}=(1 / t) \int_{0}^{t} N_{A} d t$ の夙俰学用 wて次式

$$
N_{A}=2\left(A_{1}+F_{t}-A_{0}-F_{0}\right) \sqrt{D_{A} / \pi t}
$$

の上ラКなるから，反応保数 $\beta$ を次式

$$
N_{\Lambda}=\beta\left(2 \sqrt{D_{A} / \pi t}\right)\left(A_{1}-A_{0}\right)
$$

のよ5に定無すれば

$$
\beta=1+\left[\left(F_{i}-F_{0}\right) /\left(A_{i}-A_{0}\right)\right]
$$

となる。

Eq. (A-3) は気洨界面でる成り立つから，各成分の界面浱度 $A_{i}, B_{t}, E_{t}, F_{t}$ 相互間に性 $E_{t} F_{t} / A_{t} B_{t}=K$ の成倸が成立し，

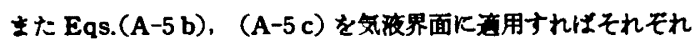
$B_{t}+F_{t}=B_{0}+F_{0}, E_{t}-F_{t}=E_{0}-F_{0}$ の成係か得られる。これら

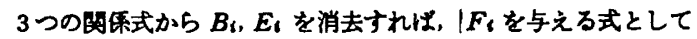
次式

$$
\begin{aligned}
F_{i}= & (1 / 2)\left[\sqrt{\left(K A_{i}+E_{0}-F_{0}\right)^{2}+4 K A_{i}\left(B_{0}+F_{0}\right)}\right. \\
& \left.-\left(K A_{i}+E^{0}-F_{0}\right)\right]
\end{aligned}
$$

が得られるから、これを Eq.(A-8)に代入して整理すれぱ， $\beta$ を与える式は啀的につぎのよ5になる。

$\beta=1+$

$$
\frac{\sqrt{\left(\frac{E_{0}}{A_{i}}+\frac{F_{0}}{A_{i}}+K\right)^{2}+4 K\left(\frac{B_{0}}{A_{i}}\right)\left(1-\frac{A_{0}}{A_{i}}\right)}-\left(\frac{E_{0}}{A_{i}}+\frac{F_{0}}{A_{i}}+K\right)}{2\left(1-\frac{A_{0}}{A_{i}}\right)}
$$

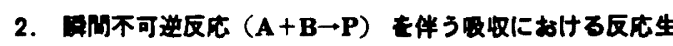

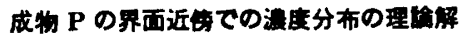

この掦合の $A, B, P$ 洛成分の液相内払散に対与る基碄微分方

程式は，浸透説にもとつけば

$$
\begin{array}{ll}
\partial A / \partial t=D_{A}\left(\partial^{2} A / \partial x^{2}\right) & \left(0<x<x^{\prime}\right) \\
\partial B / \partial t=D_{B}\left(\partial^{2} B / \partial x^{2}\right) & \left(x^{\prime}<x<\infty\right) \\
\partial P / \partial t=D_{P}\left(\partial^{2} P / \partial x^{2}\right) & (0<x<\infty)
\end{array}
$$

で与元られ，初期策件，境界条件はつぎの上5になる。

$$
\left.\begin{array}{rl}
t=0, & x>0 ; \quad B=B_{0}, P=P_{0} \\
x=0, t>0 ; & A=A_{t}, \partial P / \partial x=0 \\
x \rightarrow \infty, t \geq 0 ; & B=B_{0}, P=P_{0} \\
x=x^{\prime}, t>0 ; & A=0, B=0, \\
& -D_{\perp}(\partial A / \partial x)=D_{B}(\partial B / \partial x) \\
= & D_{P}(\partial P / \partial x)_{-}-D_{P}(\partial P / \partial x)_{+}
\end{array}\right\}
$$

ただし $x^{\prime}$ は反応面の位疅を表わし，また Eq.(A-11) の权後の 来件式中の $(\partial P / \partial x)-, （ \partial P / \partial x)+$ はそれそれ反応面における $P$ 成分の界面側，液本体側の渡度勾祀を表わす。

Eq. (A-10) Eq.(A-11) の条件下で解いて各成分の䈨度分 布を求めると, $A, B$ 両成分Kついては Sherwood ら0がすでK 与えた式と同し式が得られ，P成分についてはつぎの上ラな式 が得られる。

$$
\begin{aligned}
& x^{\prime}<x<\infty: \\
& P=P_{0}+B_{0} \sqrt{\frac{D_{B}}{D_{P}}} \exp \left[\sigma^{2}\left(\frac{D_{A}}{D_{P}}-\frac{D_{A}}{D_{B}}\right)\right] \frac{\operatorname{erfc}\left(x / 2 \sqrt{D_{P t}}\right)}{\operatorname{erfc}\left(\sqrt{D_{A} / D_{B}} \sigma\right)} \\
& \quad(\mathrm{A}-12 \mathrm{a}) \\
& 0<x<x^{\prime}: \\
& P=P_{0}+B_{0} \sqrt{\frac{\overline{D_{B}}}{D_{P}}} \exp \left[\sigma^{2}\left(\frac{D_{A}}{D_{P}}-\frac{D_{A}}{D_{B}}\right)\right] \frac{\operatorname{erfc}\left(\sqrt{D_{A} / D_{P}} \sigma\right)}{\operatorname{erfc}\left(\sqrt{D_{A} / D_{B}} \sigma\right)}
\end{aligned}
$$

ただしこれらの式中の。は Eq. (3c) の根である。Eq.(A-12b) は $x, t$ を含まないから, 気泿界面から反面までの間では $P$ 成 分忙広吸収の進行中一定浱度を保持していることがわかる。

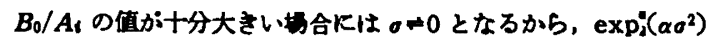
$-1, \operatorname{erfc}\left(\alpha^{\prime} \sigma\right)+1-(2 / \sqrt{x}) \alpha^{\prime} \sigma$ の近似か可能となり, Eqs.(A -12 b)，(3c) 加 $P$ 成分の文液界面近傍での一定湛度 $P_{c}$ を与 える近似式として次式が得られる。

$$
P_{C}=P_{0}+\sqrt{D_{B} / D_{P}} B_{0}
$$

\section{Nomenclature}

\section{$A$ : concentration of $\mathrm{A}$, the gas being absorbed} [g-moles $/ l]$

$A_{1}$ : equilibrium concentration of $\mathrm{A}$ at the interface (physical solubility of $A$ in solution) $\left[\mathrm{g} / \mathrm{cm}^{3}\right]$ or $[\mathrm{g} \cdot \mathrm{moles} / \mathrm{l}]$

$A_{1 \text { w }}$ : physical solubility of $A$ in water $\left[\mathrm{g} / \mathrm{cm}^{3}\right]$

$B$ : concentration of $B$, the reactant reacting with A

[g-moles/l]

$D$ : liquid-phase diffusivity (subscripts refer to species)

$\left[\mathrm{cm}^{2} / \mathrm{sec}\right]$

$E, F$ : concentration of $E, F$, the reaction products [g-moles $/ l]$

$I$ : ionic strength of the solution [g-ion $/ l]$

$K$ : equilibrium constant for reaction $\mathrm{A}+\mathrm{B} \rightleftharpoons$ $\mathrm{E}+\mathrm{F}$

$k_{\imath}$ : salting effect parameter, defined by Eq.(5) [l/g-ion]

$N_{A 1}, N_{A}$ : instantaneous and average absorption rates of $\mathbf{A}$ with chemical reaction, respectively $\left[\mathrm{g} / \mathrm{cm}^{2} \cdot \mathrm{sec}\right]$ or $\left[\mathrm{g} \cdot \mathrm{moles} / \mathrm{cm}^{2} \cdot \mathrm{sec}\right]$

$N_{A^{*}}$ : average absorption rates of $A$ without chemical reaction

$\left[\mathrm{g} / \mathrm{cm}^{2} \cdot \mathrm{sec}\right]$

$P$ : concentration of $P$, the reaction product [g-moles/l]

$P_{c}$ : constant concentration of $\mathrm{P}$ between the interface and the reacting planel[g-moles $/ l]$

$r:$ reaction rates $[\mathrm{g} \cdot \mathrm{moles} / \mathrm{l} \cdot \mathrm{sec}]$

$T$ : total concentration of the reactant, both reacted and unreacted [g-moles $/ l]$

$t$ : contact time between gas and liquid [sec]

$x$ : distance from gas-liquid interface [cm]

$x^{\prime}$ : distance from gas-liquid interface to reaction plane

[cm]

$\beta$ : reaction factor, $N_{A} / N_{A}^{*}$

$\sigma$ : parameter defined by Eq. $(3 \mathrm{c})$ 


\section{Literature cited}

1) Arrhenius, S.: Z. Physik. Chem, 10, 51 (1892)

2) Astarita, G. and F. Gioia: Chem. Eng. Sci., 19, 963 (1961)

3) Astarita, G, F. Gioia and C. Balzano: ibid, 20, 1101(1965)

1) Brian, P.L.T, J.E. Vivian and D.C. Matiatos: A. I. Ch. E. Journal, 13, 28 (1967)

5) Goldschmidt, H. and H. Larsen: Z. Physik. Chem., 71, 437 (1910)

6) Hagenbach, A.: Ann. Physik und Chemie, 65, 673 (1898)

7) Hikita, H. and S. Asai: Kagaku Kōgaku, 28, 1017 (1964)

8) Seriven, L.E. and R. L. Pigford: A. I. Ch. E. Journal, 4, 139 (1958)
9) Sherwood, T. K. and R.L. Pigford: Absorption and Extraction, 2 nd ed., 332 (1952)

10) van Krevelen, D.W. and P. J. Hoftijzer: Chim. Industr. XXI ${ }^{\circ m}$ Congr., Int. Chim. Ind, 168 (1948)

11) van Krevelen, D. W., P. J. Hoftijzer and F. J. Huntjens: Rec. trav. chim., 68, 191 (1949)

12) Vinograd, J. R. and J.W. McBain: J. Am. Chem. Soc, 163, 2008 (1941)

13) Winkler, L.W.: Mathematikai ès Természettudomanyi Ertesito, Budapest, 25, 86 (1907)

\section{気泡塔におけるヘンスアルデヒトの液相空妏酸化* 一二更境期説の道用による総括反応速度の解析一}

$$
\begin{gathered}
\text { 中 尾 実**.㯪 田 栄 } \\
\text { 大 竹 伝 } \text { 雄 }^{* * * *} \\
\text { 大阪大学 基礎工学部** }
\end{gathered}
$$

\section{娄}

著者らは先に液相内の反応速度が容解ガスについて1 论である気液系反底を二重境獏説に基ついて理諭的に解 析し，総括反应速度 $R_{A}$ K対応する正反应俰数 $\beta^{*} \equiv$ $R_{A} / a k_{L} C_{A}$ が一般に反应速度と払散速度の比に関する

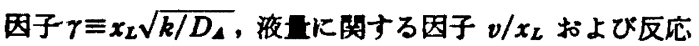
溶質渡度飞関する因子 $q \equiv D_{B} C_{B Z} / \nu D_{A} C_{A 1}$ の 3 因子に上 って影箅されることを示したり。これら 3 因子の5ち気 液系反応を规定する第一莪的な因子は 棬成与る速度定数 $k$ ，払散俰数 $D_{4}$ および液境膜厚さ $x_{L}$ または液側物質移動係数 $k_{L}$ なとの基礎定数を直接実験

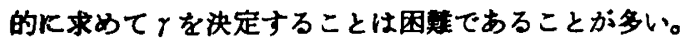
この困嚾を避けるために前述の理論的解析の際， $\gamma$ を助 变数とする $\beta^{*}$ vs. $v / x_{\boldsymbol{Z}}$ 線図または $\beta^{*}$ vs. $q$ 線四を用 いてrを決定する方法を提案した。

一方ペンズフルデヒドの液相空気酸化反応汇関して液
って, ベンズアルデヒドの酸素による酸化反応速度の測 定を試み，低酸素濩度の場合に一般に知られているよう

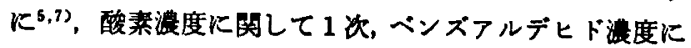
関して0次とみなせることがわかった。

本研究では液回分式気泡塔においてベンズフルデヒド の液相空気酸化反纫を実施した。そして中間体である過 安息香酸港度が無視されるが、112) あるいは一定とみなさ れる"安息香酸生成段階におけける総括反応速度 $R_{4}$ を, 種々の温度，ガス流量および酸亲分王の下で測定した。 さらにこれら操作変数が総括反応速度に及ぽす影零を考

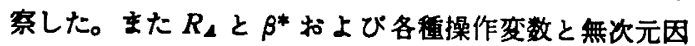

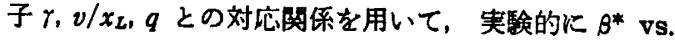
$v / x_{\boldsymbol{L}}$ の関係をるとめ $\gamma$ の值を决定することを試みた。 その結果を用いて払散抵抗の影䁹の程度が操作条件によ ってどのように変化するかを定典的に示した。 相内の湲度变化をボーラロクララフ的に追䟣することによ

* <The Liquid-Phase Oxidation of Benzaldehyde in the Gas Bubble Column - An Application of Two-Film Theory to the Analysis of Overall Reaction Rate- $>$ Received on June 9, 1967

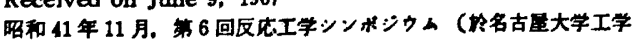

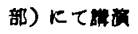

* Katsumi Nakao (大阪大学工学部 Faculty of Engineer. ing, Osaka University, Osaka, Japan),

*** Eichi Kunugita and Tsutao Otake (Faculty of Enginee. ring Science, Osaka University, Toyonaka, Japan) 


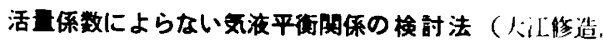

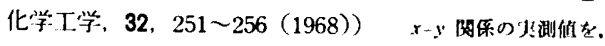

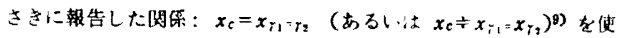

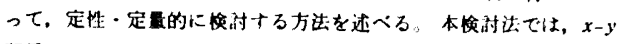

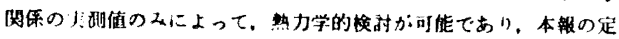

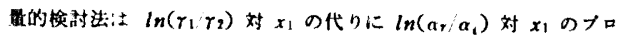
ットを用いることにより。 Herrington つ饭的法を沸点の与交ら

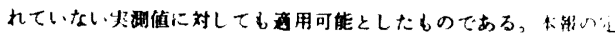

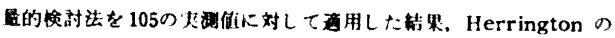

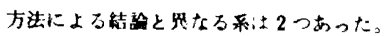

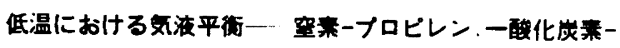

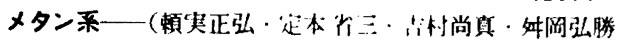

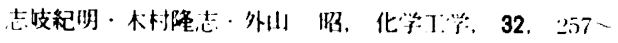

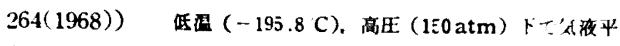

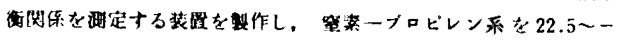

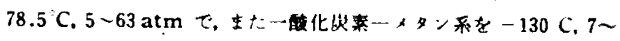
$40 \mathrm{~atm}$ の聿で湖定した。

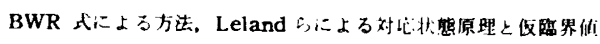

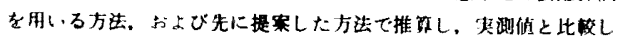
た。 Leland らの方法:士央明值と少しはずれたが。他はといによく

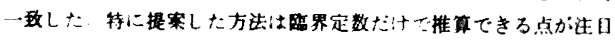
される;

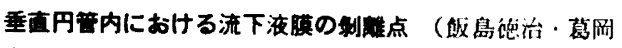

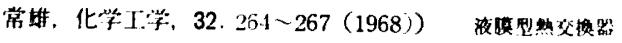

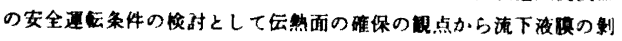

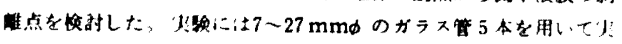

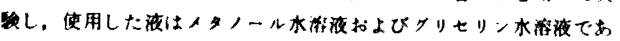

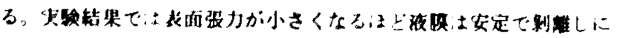

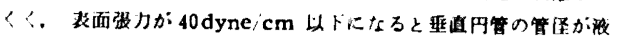

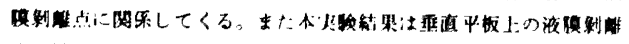
占の推相にし用てきると考えられる

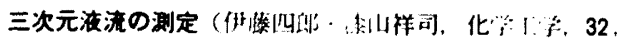

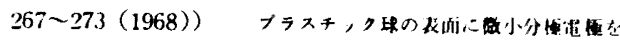

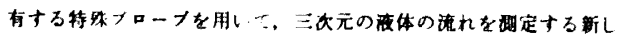

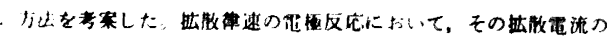

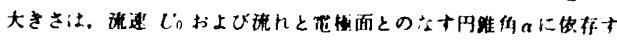

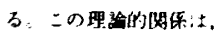

$i_{d}=K C_{i} i^{1 / 2}\left(r-0.332 j a^{3}+0.0421 a^{5}-0.00259 n^{i}\right)^{1 / 3}$ $=-7 . \quad K=0.776 \frac{c_{b} n F a D^{2 / 3}}{r(4 / 3)(R \nu)^{1 / 6,1 / 3}}$

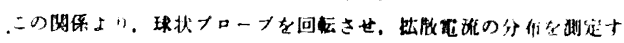

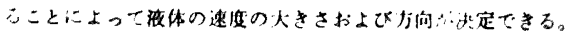

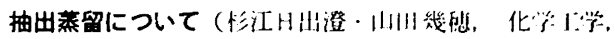

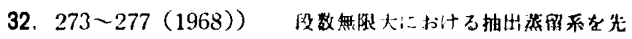

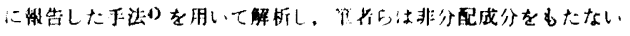

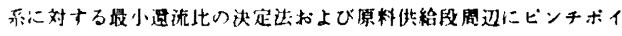

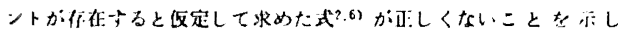
た。

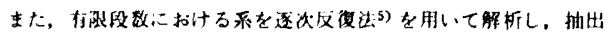
箱的計旅法を明らかにした。

アンモニアおよび苛性ソーダ水溶液による硫化水来の吸

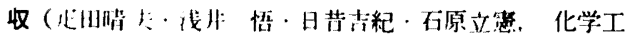

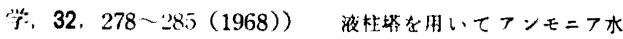

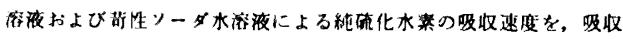

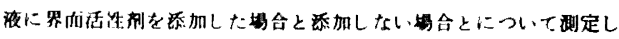

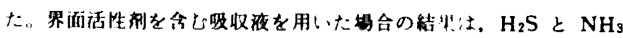

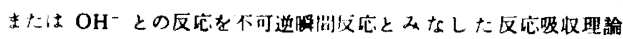

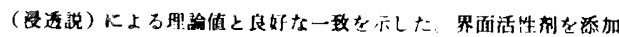

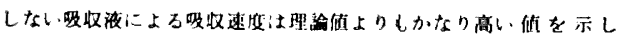

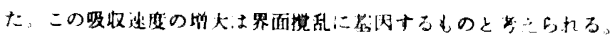

気泡塔におけるベンズアルデヒドの液相空弐醇化一 重境膜説の商用による括反忘速度の解析一（中尾勝

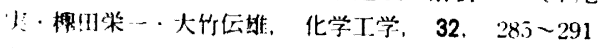

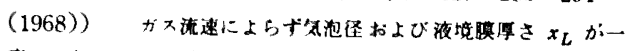

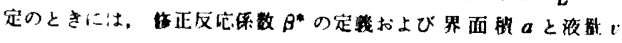

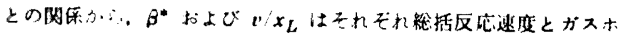

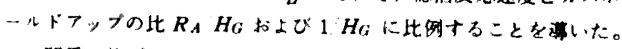

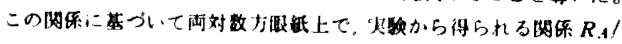
$H_{G}$ vs. $1 H_{f i}$ を平行移動してこれとよく一政する，r助变数と

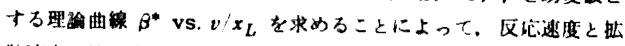

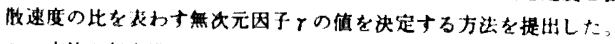

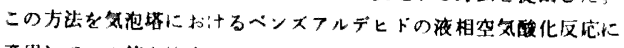
通用してての值を沈定したその結果、ガスホールドフッブによる

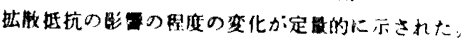

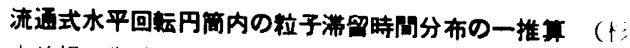
使益䙺，化学工学，32，291２97（1968））流通式水平

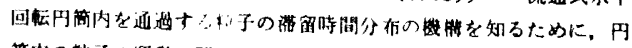

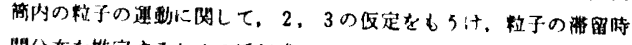

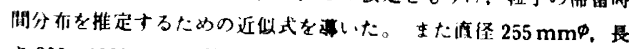

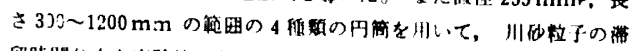

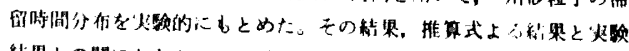
档果との間にかなりよい一政を得た。
} 